A N N A L E S

UNIVERSITATIS MARIAE CURIE-SKŁODOWSKA

LUBLIN - POLONIA

VOL. LXIX, z. 1-2

SECTIO F

2014

Uniwersytet Marii Curie-Skłodowskiej w Lublinie

Wydział Humanistyczny

\title{
PIOTR SĘCZYK
}

\section{Zarys historyczny parafii prawostawnego Soboru Katedralnego Narodzenia NMP w Białej Podlaskiej w latach 1875-1917}

Historical Overview of the Parish Council Orthodox Cathedral of the Blessed Virgin Mary in Biala Podlaska in the Years 1875-1917

\section{STRESZCZENIE}

Prawosławny Sobór Narodzenia NMP powstał w 1875 r. z byłej cerkwi po bazylianach. Od początku funkcję proboszczów w parafii sprawowali duchowni z tytułem protojereja, do pomocy mieli dwóch kapłanów oraz diakona. Parafia rozwijała się dynamicznie pomimo materialnego ubóstwa i oporu byłych unitów. Należały do niej filie: cerkiew w miejskim szpitalu w Białej, Sławacinku, Wólce Plebańskiej, Hrudzie i Ciciborze. Prawosławne duchowieństwo brało czynny udział w życiu kulturalnym i społecznym miasta i parafii oraz podejmowało akcje charytatywne wśród unitów. Działalność soboru przerwała I wojna światowa, majątek cerkiewny ewakuowano w głąb Rosji, a świątynię przejęli ewangelicy.

Słowa kluczowe: prawosławie w Królestwie Polskim; Biała Podlaska; cerkiew; Bazylianie; cerkiew prawosławna; Jozafat Kuncewicz

\section{WPROWADZENIE}

Niniejszy artykuł przedstawia zarys historyczny parafii prawosławnego Soboru Katedralnego w Białej Podlaskiej w latach 1875-1917. Podstawę źródłową stanowią akta Prawosławnego Konsystorza Chełmsko-Warszawskiego, Chełmskiego Konsystorza Prawosławnego, Chełmskiego Zarządu Duchownego oraz Starostwa Powiatowego w Białej Podlaskiej. Wykorzystano również artykuły 
z prasy urzędowej Królestwa Polskiego opublikowane w takich czasopismach, jak „Pamiatnaja Kniżka Siedleckoj Guberni” z lat 1875-1913 i „Chołmskaja Gubernia 1914 God” (roczniki), oraz czasopisma cerkiewne, szczególnie z lat 18751917 i późniejszych. Z periodyków religijnych wybrano pisma: „Chołmsko-Warszawskij Jeparchialnyj Wiestnik” ukazujący się w Warszawie (dwutygodnik w latach 1877-1899, następnie tygodnik w latach 1900-1905), „Chołmskaja Cerkownaja Żizn” (dwutygodnik) z Chełma, „Cerkownyja Wiedomosti” z Petersburga (tygodnik) i „Wiadomości Polskiego Autokefalicznego Kościoła Prawosławnego" z Białegostoku (miesięcznik). Pierwsze dwa czasopisma religijne były skierowane do wiernych prawosławnych zamieszkujących tereny Królestwa Polskiego. Po powstaniu prawosławnej eparchii chełmskiej w 1905 r. utworzono dla niej diecezjalny periodyk „Chołmskaja Cerkownaja Żizn”. Natomiast „Cerkownyja Wiedomosti” rozprowadzano w całym Cesarstwie Rosyjskim i poza jego granicami.

We wszystkich wymienionych czasopismach artykuły publikowali przeważnie prawosławni duchowni, zdarzały się też inicjatywy osób świeckich. Głównym celem wydawców prasy było informowanie na bieżąco duchownych i świeckich o postanowieniach wyższych władz duchownych Rosyjskiej Cerkwi Prawosławnej. Umieszczone daty w artykule zostały zapisane zgodnie $\mathrm{z}$ kalendarzem gregoriańskim.

\section{DUSZPASTERSTWO I PODZIAŁ ADMINISTRACYJNY PARAFII}

Prawosławna Parafia Katedralna Narodzenia NMP w Białej Podlaskiej powstała w $1875 \mathrm{r}$. w miejscu, gdzie wcześniej funkcjonowała unicka wspólnota religijna. Należały do niej następujące miejscowości: część miasta Biała, Sławatin, Styriniec, Sielce, Grabanowo, Wólka Plebańska. Nazwy te już w drugiej połowie XIX w. młodzież wypowiadała w polskiej wersji: Sławacinek, Styrzyniec, Sielczyk, Grabanów, zaś starsze pokolenie używało wcześniejszych rusińskich nazw. Stiepan Gromeka - siedlecki gubernator - w 1869 r. zalecał duchownym unickim posługiwać się $\mathrm{w}$ urzędowych dokumentach nazwami miejscowości według starego brzmienia $\mathrm{w}$ języku rusińskim. Zalecenie to nie zostało powszechnie wprowadzone na terenie guberni siedleckiej z powodu niechęci urzędników państwowych.

W 1907 r. do parafii przyłączono zlikwidowaną cerkiew w Hrudzie wraz z całym cerkiewnym majątkiem, natomiast w 1909 r. cerkiew w Ciciborze ${ }^{1}$.

${ }^{1}$ M. Liwczak, Письмо в редакциию, «Холмско Варшавский Епархиальный Вестник» (dalej: XВEB), № 5, 13 III 1896, s. 101-102; Указ святейшего Синода Преосвященному Евлогию Епископу Холмскому от 15 мая 1907 г. за нр 5823, «Холмская Церковная Жизнь» (dalej: ХЦЖ), № 12, 28 VI 1907, s. 416; По указу его императорского величества, ХЦЖ, № 6, 28 III 1909, s. 203. 
Świątobliwy Synod w 1877 r. ustalił stałą liczbę duchownych, którzy mieli pracować w bialskiej parafii: proboszcz protojerej otrzymywał rocznie wynagrodzenie w wysokości 1300 rubli, dwóch pomocników proboszcza pobierało po 800 rubli, diakon - 700 rubli, dwóch psalmistów po 250 rubli, trzeci zaś 200 rubli. Nie zawsze przestrzegano wytycznych wyższych władz duchownych w Petersburgu. W 1909 r. przy parafii na stałe pracował proboszcz z dwoma wikariuszami, diakonami i psalmistami (młodszym i starszym). Natomiast w $1912 \mathrm{r}$. przebywał tylko jeden diakon, ale zwiększono liczbę diaków do trzech. W kolejnym roku ponownie było dwóch diakonów i psalmistów. Dla ochrony majątku parafii w 1878 r. zatrudniono dwóch stróży cerkiewnych, którym przyznano po 100 rubli $^{2}$.

Bialski sobór graniczył z innymi probostwami: cerkwią św. Cyryla i Metodego w Białej Podlaskiej, Woskrzenicami, Ciciborem, Sworami, Hrudem. W 1880 r. nastąpił podział dekanatu bialskiego na dwa okręgi w eparchii chełmsko-warszawskiej. Prawosławna parafia w Białej została przydzielona do I bialskiego dekanatu. W niektórych latach funkcje dziekanów pełnili proboszczowie z bialskiego soboru. Wspólnota religijna Narodzenia NMP w Białej należała do jednych z największych prawosławnych parafii w dekanacie. W $1886 \mathrm{r}$. pierwsze miejsce zajmowała cerkiew w Łomazach z liczbą wiernych $3351^{3}$.

Stan liczebności wiernych bialskiego soboru gwałtownie obniżył się, jak wskazują dane zamieszczone w tab. 1, po 1905 r. Przyczynę tego zjawiska należy upatrywać w masowych konwersjach unitów, których oficjalnie wcześniej zaliczano do prawosławnych.

Tab. 1. Liczba wiernych w wybranych latach parafii Bialskiego Katedralnego Soboru NNMP

\begin{tabular}{|c|c|c|c|}
\hline Rok & Liczba mężczyzn & Liczba kobiet & Liczba wiernych parafii \\
\hline 1878 & 950 & 1038 & 1988 \\
\hline 1905 & 1573 & 1621 & 3194 \\
\hline 1907 & 403 & 413 & 816 \\
\hline 1908 & 413 & 423 & 836 \\
\hline 1912 & 606 & 573 & 1179 \\
\hline 1914 & 700 & 682 & 1382 \\
\hline
\end{tabular}

Źródło: APL, Клир. Вед., sygn. 6, s. 13; sygn. 50, s. 25; sygn. 54, s. 21; sygn. 55, s. 17; sygn. 56, s. 19 ; sygn. 62 , s. 26.

2 Духовенство православного исповедания. Бельское благочиние 1-го округа, «Памятная Книжка Седлецкой Губернии за 1909 год», s. 178; Духовенство православного исповедания. Бельское благочиние 1-го округа, «Памятная Книжка Седлецкой Губернии за 1912 год», s. 160; Archiwum Państwowe w Lublinie (dalej: APL), Клировые Ведомости (dalej: Клир. Вед.), sygn. 6, s. 1 .

${ }^{3}$ Приходское духовенство в Седлечкой губернии Бельское благочиние 1-го округа, «Памятная Книжка Седлецкой Губернии за 1911 год», s. 134. 
Przez 40 lat działalności parafii funkcje proboszczów pełniło pięciu prezbiterów. $\mathrm{Z}$ duchownych, którzy najdłużej pracowali, należy wymienić Teodora Baranowskiego. Przebywał na placówce ponad 36 lat - początkowo jako diakon, w 1907 r. przyjął święcenia kapłańskie, zmarł 24 marca 1914 r. ${ }^{4}$ Częsta rotacja na stanowiskach występowała głównie wśród wikarych (zob. tab. 2).

Przed zbliżającym się frontem w 1915 r. na uchodźstwo wyjechali wszyscy duchowni parafii i część parafian, np. ks. Antoni Lubarski wyemigrował do miasta Pryłuki (północna Ukraina), a ks. Teodozy Lewicki do wsi Blinowa koło miasta Kaługi ${ }^{5}$.

3 kwietnia 1916 r. Świątobliwy Synod wybrał biskupa sufragana chełmskiej eparchii, bpa Serafina, byłego rektora Chełmskiego Seminarium Duchownego Michała Mitrofanowicza Ostroumowa. Przyjęcie sakry biskupiej (tzw. chirotonia) dokonało się w Soborze Chrystusa Zbawiciela w Moskwie, tam też urzędował nowy władyka. Bialski sobór został wybrany na katedrę, jednak świątynia pozostawała nadal w rękach ewangelików. Serafin przyjął tytuł biskupa bielskiego, nigdy jednak nie powrócił do Białej. Rok później objął eparchię orłowską na terytorium Rosji ${ }^{6}$.

\section{ZAPLECZE EKONOMICZNE}

Bialski sobór (świątynia) pierwotnie został wzniesiony przez Radziwiłłów w latach 1747-1759 dla potrzeb grekokatolickiego zakonu bazylianów w celu krzewienia unii brzeskiej wśród prawosławnego ludu w Białej i okolicach. Po kasacie klasztoru w 1864 r. i unickiej diecezji chełmskiej w 1875 r., świątynia stała się ośrodkiem kultu Kościoła prawosławnego. Z powodu okazałości cerkwi i jej rozmiarów w 1875 r. nadano jej tytuł soboru, był to największy unicki budynek sakralny na Południowym Podlasiu. Nazwa bialski sobór pochodziła od usytuowania cerkwi w mieście Biała, podobne nazwy nadano innym świątyniom, np. sobór siedlecki, chełmski, warszawski itp.?

Cerkiew Narodzenia NMP przebudowano w 1882 r., dodatkowo wzniesiono na wieżach świątyni dwie kopuły. Projekt przebudowy budynku sakralnego opracował Wiktor Szyczugow ${ }^{8}$. Kolejny gruntowny remont świątyni przeprowadzo-

${ }^{4}$ APL, Starostwo Powiatowe Bialskie, sygn. 197, s. 40-41.

${ }^{5}$ APL, Chełmski Konsystorz Prawosławny (dalej: ChKР), sygn. 4425, s. 524; Исход сельских прихожсан Бельского собора из города Бель и их жизн в изгнани, ХЦЖ, № 13-16, 14 VII 28 VIII 1917, s. 237-238; Адреса священников Холмской епархии, ХЦЖ, № 14, 28 XII 1915, s. 6-14; Адреса священников Холмской епархии, ХЦЖ, № 13, 14 XII 1915, s. 9-14.

${ }^{6}$ Преосвященнейший Серафим епископ белский, ХЦЖ, № 7-8, 28 IV 1916, s. 121-127.

${ }^{7}$ I. W., Заметка о древнем православном монастыре в Левкове (Докудов, Бельского уезда, Седлеикой губернии), ХВЕВ, № 3, 13 II 1886, s. 37-39.

${ }^{8}$ Wiktor Szyczugow - ur. 1837 r. w Petersburgu, zm. 23 czerwca 1892 r. w Warszawie, ukończył Akademię Sztuk Pięknych w stolicy Rosji. 
Tab. 2. Spis prawosławnych duchownych, którzy pracowali w latach $1875-1915 \mathrm{w}$ prawosławnej parafii Narodzenia NMP w Białej Podlaskiej

\begin{tabular}{|c|c|c|c|c|c|}
\hline $\begin{array}{c}\text { Imię } \\
\text { i nazwisko } \\
\text { proboszcza }\end{array}$ & $\begin{array}{c}\text { Lata } \\
\text { pelnienia } \\
\text { funkcji }\end{array}$ & $\begin{array}{l}\text { Imię i nazwisko } \\
\text { wikariusza }\end{array}$ & $\begin{array}{c}\text { Lata } \\
\text { pelnienia } \\
\text { funkcji }\end{array}$ & $\begin{array}{l}\text { Imię i nazwisko } \\
\text { diakona }\end{array}$ & $\begin{array}{c}\text { Lata } \\
\text { pelnienia } \\
\text { funkcji }\end{array}$ \\
\hline $\begin{array}{l}\text { Mikołaj } \\
\text { Liwczak }\end{array}$ & $1875-1880$ & $\begin{array}{c}\text { Anastazy } \\
\text { Straszkiewicz }\end{array}$ & 1878 & $\begin{array}{c}\text { Teodor } \\
\text { Baranowski }\end{array}$ & $1878-1907$ \\
\hline $\begin{array}{c}\text { Apolinari } \\
\text { Kowalnicki }\end{array}$ & $1881-1886$ & $\begin{array}{l}\text { Aleksander Izydor } \\
\text { Mogilnicki }\end{array}$ & $1878-1879$ & $\begin{array}{c}\text { Michał } \\
\text { Szczurowski }\end{array}$ & 1908-1912 \\
\hline $\begin{array}{c}\text { Symeon } \\
\text { Michalewicz }\end{array}$ & 1887-1902 & Nikanor Wielecki & $1878-1880$ & $\begin{array}{c}\text { Stefan } \\
\text { Gawłowski }\end{array}$ & 1908-1909 \\
\hline $\begin{array}{c}\text { Jan } \\
\text { Juchnowski }\end{array}$ & 1903-1905 & Sylwester Gorski & 1880 & Józef Korol & 1909-1911 \\
\hline \multirow[t]{18}{*}{$\begin{array}{l}\text { Antoni } \\
\text { Lubarski }\end{array}$} & $1906-1915$ & Jan Kozakiewicz & $\begin{array}{l}1882-1890 \\
1892-1899\end{array}$ & $\begin{array}{c}\text { Stefan } \\
\text { Nowosielski }\end{array}$ & 1913 \\
\hline & & Jelewferi Zalenski & $1882-1884$ & $\begin{array}{l}\text { Mikołaj } \\
\text { Gering }\end{array}$ & 1913 \\
\hline & & Piotr Gapanowicz & $1885-1887$ & $\begin{array}{c}\text { Apollon } \\
\text { Skałozubow }\end{array}$ & 1914 \\
\hline & & Jakub Syrojedow & 1888 & Józef Rawlik & 1914 \\
\hline & & Antoni Telechowski & 1889 & & \\
\hline & & Józef Dochniak & 1890-1906 & & \\
\hline & & Dmitri Szimkiewicz & 1891 & & \\
\hline & & Stefan Gruszka & 1900-1901 & & \\
\hline & & $\begin{array}{l}\text { Wiaczesław } \\
\text { Chlebcewicz }\end{array}$ & $1902-1903$ & & \\
\hline & & Antoni Jurewicz & 1905 & & \\
\hline & & Mikołaj Doroszuk & 1906 & & \\
\hline & & Józef Baczinski & 1907 & & \\
\hline & & Józef Kras & 1907 & & \\
\hline & & Teodor Baranowski & 1908-1914 & & \\
\hline & & Roman Aresztowicz & 1909-1911 & & \\
\hline & & Jan Jakimiuk & $1912-1913$ & & \\
\hline & & Grzegorz Nikołajuk & 1914 & & \\
\hline & & Teodozjusz Lewicki & 1915 & & \\
\hline
\end{tabular}

Źródło: Приходское духовенство в Седлеиякй губернии Бельское Благочиние 1-го Округа, «Памятная Книжка Седлецкой Губернии» 1875-1913; Духовенство православного исповедания, «Холмская губерния 1914 г.»; Исход сельских прихожан Бельского собора из города Бель и их жизн в изгнани, ХЦЖ, № 13-16, 14 VII - 28 VIII 1917, s. 237-238; Адреса священников Холмской епархии, ХЦЖ, № 14, 28 XII 1915, s. 6-14; Адреса священников Холмской епархии, ХЦЖ, № 13, 14 XII 1915, s. 9-14. 
no w latach 1888-1900, poświęcenia dokonał bp Flawian 8 marca 1891 r. Na uroczystości przybyło 12 prawosławnych duchownych, przedstawiciele władz cywilnych i wojskowych oraz ihumenia Katarzyna Jefimowska ${ }^{9}$ z siostrami zakonnymi z Leśnej Podlaskiej ${ }^{10}$.

Prawosławna parafia przejęła w 1875 r. część majątku po unickiej parafii w Białej - 95 morgów i 150 prętów ziemi rolnej i 7 morgów 150 prętów łąk, 7 morgów ogrodów z zabudowaniami gospodarczymi ${ }^{11}$. W latach 80 . XIX w. duchowni soboru próbowali przyłączyć do parafii las o powierzchni 25508 dziesięcin położony w Puszczy Bialskiej na uroczysku: Dzicze, Ostrówek i przy Szopie. $\mathrm{Z}$ powodu braku notarialnych dokumentów do prawa posiadania wyżej wspomnianego lasu, dobra te przeszły na własność książąt Hohenlohe. Do końca istnienia parafii jednak toczył się spór o jego przynależność. Siedlecka Izba Skarbowa zwróciła 4 grudnia 1883 r. duchownym dodatkowe 83 morgi gruntu, który planowano sprzedać na publicznej licytacji ${ }^{12}$.

W wyniku postanowienia komisarza do spraw włościańskich guberni siedleckiej 10 grudnia $1884 \mathrm{r}$. bialski sobór otrzymał prawo do korzystania z leśnego serwitutu: rocznie 90 jednokonnych wozów drewna przeznaczonego na ogrzewanie budynków i pięć sztuk na materiał. Poszczególni duchowni pobierali drewno: proboszcz 24 wozy, wikariusze po 16, diakon - 12, psalmiści - osiem i sześć. Właściciel dóbr Białej w 1904 r. zabronił duchownym eksploatowania prywatnych lasów, w wyniku decyzji książąt Hohenlohe zostało wniesione zawiadomienie do prokuratury Królestwa Polskiego ${ }^{13}$.

Część księży posługujących w parafii mieszkało w piętrowym budynku po dawnym bazyliańskim klasztorze. Protojerej zajmował siedem pokoi mieszkalnych i kuchnię, diakon cztery pomieszczenia, natomiast psalmiści po jednym z kuchnią. Pomocnicy proboszcza (wikariusze) ze swoimi rodzinami przebywali w oddzielnym budynku wzniesionym po 1895 r. na miejscu zniszczonego przez pożar domu parafialnego z 1882 r. $^{14}$

${ }^{9}$ Eugenia Jefimowska - ur. 9 września 1850 r. w Moskwie, zm. 28 października 1925 r. w miejscowości Nowe Opowo. Była założycielką i przełożoną w latach 1886-1908 prawosławnego żeńskiego monasteru w Leśnej Podlasce.

${ }^{10}$ A. Bobryk, I. Kochan, Ślady przeszłości. Historia i teraźniejszość prawosławia na południowo-zachodnim Podlasiu w świadomości społecznej, Siedlce 2010, s. 145-146; G.J. Pelica, Dzieje parafii świętych Cyryla i Metodego w Biatej Podlaskiej, „Wiadomości Polskiego Autokefalicznego Kościoła Prawosławnego" 2010, nr 2 (243), s. 16-17.

${ }^{11}$ APL, Komisarz do Spraw Włościańskich Powiatu Bialskiego, sygn. 71, s. 4-30.

${ }^{12}$ APL, Chełmsko-Warszawski Duchowny Konsystorz Prawosławny (dalej: ChWDKP), sygn. 81, s. 1-8, 73-74, 140-144.

${ }^{13}$ APL, Клир. Вед., sygn. 62, s. 4; Клир. Вед., sygn. 52, s. 2.

${ }^{14}$ APL, Клир. Вед., sygn. 55, s. 2; APL, Chełmski Zarząd Duchowny (dalej: ChZD), sygn. 2476, s. 301-302. 
Obecność przy soborze na stałe trzech duchownych stwarzała możliwość przyłączenia do parafii innych cerkwi, tzw. filii. Domowa cerkiew pw. św. Aleksandra Newskiego przy męskim gimnazjum w Białej stała się częścią parafii decyzją arcybiskupa chełmsko-warszawskiego. W dniach 11-17 sierpnia $1884 \mathrm{r}$. jeden $\mathrm{z}$ duchownych $\mathrm{z}$ soboru nauczał $\mathrm{w}$ gimnazjum katechezy ${ }^{15}$. Kolejną świątynią, którą utworzono w 1888 r. z katolickiej kaplicy św. Karola Boromeusza, była cerkiew pw. św. Marii Magdaleny w miejskim szpitalu w Białej. Cerkiew zorganizowano po usunięciu ze szpitala Sióstr Miłosierdzia - Szarytek. Ich działalność, jak sądzono, przyczyniała się do przyciągania opornych unitów do Kościoła katolickiego. Szpitalem zarządzał do 1915 r. Czerwony Krzyż, który umieścił w nim prawosławne krzyżanki. Na urządzenie cerkwi zebrano ofiary w wysokości 768 rubli, z czego wykorzystano 678 rubli. Poświęcenia budynku dokonał protojerej Michaliewicz 14 października 1888 r., nabożeństwa w niej sprawowano tylko w niedziele i święta ${ }^{16}$.

Świątynia przy cerkiewnej szkole w Sławacinku również podlegała jurysdykcji soboru. Drewniany budynek wzniesiono w 1893 r., właścicielka majątku radziwiłłowskiego w Białej księżna Hohenlohe ofiarowała na budowę szkoły i cerkwi 274 sztuki najwyższej jakości drzew ${ }^{17}$. Dodatkowo na wybudowanie wyżej wspomnianych obiektów Świątobliwy Synod z Petersburga przeznaczył 2370 rubli $\mathrm{z}$ zastrzeżeniem, że w cerkwi na zawsze mają być sprawowane nabożeństwa za sługę Paraskewę (ofiarodawczynię). Cerkiewne bractwo z Moskwy przysłało niektóre przedmioty liturgiczne do sprawowania liturgii: talerzyk z podstawką na prosforę, mirnicę, mały ręczny krzyż, paschalny trójświecznik, natomiast miejscowi włościanie wioski ofiarowali plac pod budowę. Budynki wzniesiono na kamiennych fundamentach i pokryto blachą. Zostały one poświęcone przez abp Flawiana 22 października 1893 r. Szkoła mogła pomieścić do 80 uczniów, w cerkwi sprawowano nabożeństwa w niedziele i dni świąteczne ${ }^{18}$.

Duchowieństwo soboru zajmowało się opieką nad cerkiewno-parafialnymi szkołami. Jedną taką placówkę utworzono 13 września 1888 r. na terenie parafii w Sławacinku pw. św. Paraskiewy, świątynia mogła pomieścić do 45 osób. Sale lekcyjne urządzono w wynajętym budynku. Do cerkwi tej uczęszczali wierni z pobliskich miejscowości: Sławacinek, Porosiuki, Styrzyniec - na niedzielne nabo-

${ }^{15}$ Причисление домовой иееркви в Бельской гимназии к Бельскому собору, ХВЕВ, № 17, 13 IX 1884, s. 251; APL, Клир. Вед., sygn. 55, s. 1.

${ }_{16}$ Устройство и освящение иеркви в Бельиякой больнище, ХВЕВ, № 24, 27 XII 1888, s. $395-396$.

${ }^{17}$ Архипастырское благословение за пожертвования на нужду иерквей и другия заслуги по духовному ведомству, ХВЕВ, № 20, 27 X 1893, s. 330.

${ }^{18}$ Известия, ХВЕВ, № 20, 27 X 1893, s. 342-243; Отчет о деятельности Холмского Православного Свято-Богородицкого Братства состоящего под Высочайшим Его Императорскаго Величества покровителством за 1892/93 братский четырнадиатый год, ХВЕВ, № 21, 13 XI 1893, s. 361. 
żeństwa. Szkołą kierował starszy psalmista z bialskiego soboru pod nadzorem duchownego. W 1890 r. do gmachu szkolnego uczęszczało 27 dzieci, w tym 23 osoby wyznania prawosławnego, dwóch katolików i dwóch innowierców. W 1905 r. w placówce oświatowej duchowny Teodot Doronowicz zorganizował krótkookresowe, pedagogiczne kursy dla nauczycieli ${ }^{19}$.

Placówkę oświatową w Wólce Plebańskiej poświęcił ks. Michaliewicz 24 lutego 1895 r. Budynki szkoły były drewniane, wzniesione na kamiennych fundamentach. O utworzenie szkoły i świątyni usilnie zabiegała ihumenia z żeńskiego prawosławnego klasztoru w Leśnej Katarzyna Jefimowska, która na ten cel zebrała 5555 rubli. Duży wkład finansowy wniósł też prawosławny duchowny protojerej Jan Kronsztadzki, który osobiście przybył z odległego Kronsztadu i dokonał poświęcenia placu pod budowę budynków. Nabożeństwa w cerkwi dla wiernych sprawowali duchowni z bialskiego soboru w niedziele i święta ${ }^{20}$.

Do parafii należał jeden cmentarz grzebalny, który sobór przejął po grekokatolikach w 1875 r. wraz z drewnianą cmentarną cerkwią pw. św. Onufrego Wielkiego. W 1898 r. zbierano fundusze na konserwację cerkwi, hojne ofiary złożyli: księżna Hohenlohe 100 rubli i wdowa Maria Iwanowna 500 rubli. Przebudowana świątynia została na nowo oszalowana w środku i pomalowana olejną farbą. Poświęcenia dokonał protojerej Michaliewicz 28 sierpnia 1898 r., budynek mógł pomieścić 60-80 osób. Duchowni soboru zarządzali również niewielką budowlą sakralną, którą wzniesiono na grobie wspomnianego ks. Michaliewicza na prośbę jego córki w 1905 r., oraz kaplicą w miejscowym więzieniu ${ }^{21}$.

Parafia była zaliczana do ubogich materialnie, dlatego od początku do końca swego istnienia otrzymywała wsparcie finansowe i przedmioty kultu religijnego od instytucji cerkiewnych i osób prywatnych. Rocznie ze skarbu państwa przeznaczano na utrzymanie soboru 400 rubli, na remonty plebani 120 rubli, a na konserwację budynków gospodarczych 200 rubli. Dodatkowo na jej terenie mieszkali oporni grekokatolicy. W 1904 r. stwierdzono, że niektórzy unici z Białej przez 30 lat nie uczestniczyli w cerkiewnych nabożeństwach ${ }^{22}$.

W 1892 r. przysłano ikony: Zbawiciela za szkłem i drewnianą ramą, Narodzenia Pańskiego, Kazańskiej Matki Boskiej, Zbawiciela ze srebrną sukienką.

${ }^{19}$ APL, Starostwo Powiatowe Bialskie, sygn. 193, s. 216; Отчет о состоянии иерковно-приходских школ Холмско-Варшавской Епархии за 1888/9 учебный год, ХВЕВ, № 13, 13 VII 1890, s. 210; От Епархиального Училищного Совета, XBEВ, № 2, 22 I 1905, s. 18, APL, ChWDKP, sygn. 768, s. 1-17.

${ }^{20}$ APL, ChWDKP, sygn. 781, s. 1-4; Устройство и освящение иеркви-иколь в деревние Вульке Плебанской, ХВЕВ, № 6, 27 III 1895, s. 121.

${ }^{21}$ Объявления благодарности Епархиального Начальства, ХВЕВ, № 18, 27 IX 1898, s. 354; Освящения кладбищенской иеекви в городе Беле, XBEВ, № 18, 27 IX 1898, s. 371; APL, Starostwo Powiatowe Bialskie, sygn. 196, s. 7.

${ }^{22}$ APL, Клир. Вед., sygn. 54, s. 1; Народно цеерковный напев в Холмской Руси, ХВЕВ, № 37, 25 IX 1904, s. 444. 
Znaleźli się również ofiarodawcy, którzy przekazali niemałe datki na generalny remont i przebudowę świątyni, np. Mikołaj Soncow, który w 1891 r. przeznaczył na ten cel 5138 rubli; luteranin, mieszkaniec Białej, Tajbor, ofiarował 250 łokci suchego dębowego drewna na zbudowanie ołtarzy; administrator dóbr Biała (Panklia) bezpłatnie zaoferował 50 wozów drewna na ogrzewanie soboru. Innym razem zebrano 400 rubli, za które zakupiono większą ikonę Aleksandra Newskiego w dębowej oprawie ze świecznikiem ${ }^{23}$.

Parafia prowadziła gospodarstwo rolne, z którego czerpała dochody. Z 10 na 11 czerwca 1910 r. o północy wybuchł pożar, który spustoszył część zabudowań gospodarczych. Doszczętnie spłonęła szopa i spichlerz. Zniszczeniu uległ również dachy na mniejszej szopie i budynku mieszkalnym, gdzie mieszkali diakon i psalmista. Z powodu braku funduszy ks. Lubarski zwrócił się do Chełmskiego Konsystorza o wydanie 83,16 rubli na remont budynku ${ }^{24}$.

Pod koniec 1914 r. bialski sobór posiadał osiem dzwonów umieszczonych w prawej wieży świątyni. W cerkwi znajdowały się trzy ołtarze: pierwszy poświęcony na cześć Narodzenia NMP, drugi (z prawej strony) na cześć świętego Mikołaja i ostatni - św. Trójcy. Wierni wspólnoty mogli korzystać z parafialnej biblioteki, która w 1914 r. zawierała 82 tomy książek ${ }^{25}$.

W szczytowym rozwoju parafia w 1914 r. zarządzała trzema dziesięcinami ziemi i 906 sążniami kwadratowymi pod placami w mieście, 62,1431 dziesięcinami ziemi ornej, 34,118 dziesięcinami łąk, 1,613 dziesięcinami nieużytków. Ogólnie wspólnota religijna posiadała 101,668 dziesięcin zlokalizowanych w 14 częściach. Dodatkowo duchowni korzystali z gruntów byłej prawosławnej parafii w Hrudzie (w sumie 56,1437 dziesięcin), które przynosiły 300 rubli zysku z dzierżawy.

Duchowni posługiwali w miejskim szpitalu, za co otrzymywali rocznie 132 ruble, a z użytkowania cerkiewnej ziemi w pobliżu Białej pobierali 392 ruble. Innym źródłem przychodów były sumy uzyskane ze skarbonek umieszczonych przed ikonami i relikwiami świętych, np. w 1914 r. zebrano 452,49 rubli ${ }^{26}$.

Klęska wojsk rosyjskich podczas I wojny światowej i przesuwanie się niemieckich oddziałów na wschód Królestwa Polskiego zagroziły mieniu parafii, dlatego latem 1915 r. ruchomy majątek bialskiego soboru został ewakuowany w głąb

${ }^{23}$ Поступившия пожертования назначены в бедниейшия церкви Епархии, а именно, ХВЕВ, № 21, 13 XI 1892, s. 402; Архипастырское благословение за примерную заботливост благолени Храма Божия и благодарност Епархиалното Начальства за пожертвования в пользу иеркви, ХВЕВ, № 9, 13 V 1891, s. 130; Высочайшая благодарность, ХВЕВ, № 15, 13 VIII 1891, s. 229.

${ }^{24}$ APL, ChKP, sygn. 2530, s. 1.

${ }^{25}$ APL, Клир. Вед., sygn. 62, s. 2.

${ }^{26}$ Ibidem. 
Rosji. Z najcenniejszych rzeczy wywieziono: pozłacaną w srebrnej oprawie ikonę Zbawiciela, którą podarował car Aleksander II, portrety Radziwiłłów i naczynia liturgiczne. Świątynię wojska niemieckie przejęły na zbór ewangelicki²7.

\section{ŻYCIE RELIGIJNE I SPOŁECZNE PARAFII}

Sobór, od początku zaliczany do okazałych świątyń, stał się ważnym ośrodkiem szerzenia prawosławia na Południowym Podlasiu. 24 stycznia 1875 r. odbyły się tu lokalne uroczystości zjednoczenia grekokatolików z Cerkwią prawosławną. Na nabożeństwo przybyło 30 duchownych i delegacje świeckie z 45 parafiii ${ }^{28}$.

6 kwietnia 1875 r. do Petersburga udał się ówczesny proboszcz protojerej Mikołaj Liwczak wraz delegacją duchownych w celu oficjalnego zjednoczenia diecezji unickiej z Cerkwią prawosławną. Aleksander II na pamiątkę tego wydarzenia podarował Liwczakowi ikony Zbawiciela i Matki Bożej, które ten przywiózł i umieścił w cerkwi w Białej i Janowie w guberni siedleckiej29.

Początki nowego kultu w Białej były trudne. Po usunięciu relikwii św. Jozafata Kuncewicza (szczątki unickiego arcybiskupa w ozdobnym sarkofagu sprowadzono z Połocka i przechowywano w cerkwi przez ponad 100 lat) znacznie osłabł ruch pielgrzymkowy. W celu ożywienia pątnictwa planowano w $1894 \mathrm{r}$. utworzenie nowego sanktuarium. Relikwie Kuncewicza nie mogły pozostać w cerkwi, ponieważ prawosławne duchowieństwo nie uznawało greckokatolickiego świętego. Należało kult unickiego męczennika zastąpić inną zatwierdzoną przez prawosławie formą adoracji, również znaną i rozpowszechnioną na Podlasiu. W tym celu planowano sprowadzić z Soboru Kazańskiego z Petersburga kopię ikony Matki Bożej Częstochowskiej. Przewidywano utworzenie miejsca kultu religijnego na wzór Jasnej Góry dla wiernych prawosławnych z Królestwa Polskiego. Kopia ikony pochodziła z Częstochowy, przeor paulinów ofiarował ją dowódcy, Fabianowi Gottliebowi von der Osten-Sackenowi ${ }^{30}$, po przypuszczeniu szturmu przez wojska rosyjskie na Klasztor Jasnogórski w 1813 r.

${ }^{27}$ APL, ChKP, sygn. 4425, s. 524; Исход сельских прихожан Бельского собора из города Бель и их жизн в изгнани, ХЦЖ, № 13-16, 14 VII - 28 VIII 1917, s. 237-238; Адреса свяменников Холмской епархии, ХЦЖ, № 14, 28 ХІІ 1915, s, 6-14; Адреса священников Холмской епархии, ХЦЖ, № 13, 14 XII 1915, s. 9-14.

${ }^{28}$ T. Krawczyk, Zanim wróciła Polska. Martyrologium ludności unickiej na Podlasiu w latach 1866-1905 w świetle wspomnień, Warszawa 1994, s. 242-243.

${ }^{29}$ W. Osadczy, Święta Ruś. Rozwój i oddziatywanie idei prawosławia w Galicji, Lublin 2007, s. 224; К двадиатипятилетию возсоединения греко-униятов Холмской епархии с православною иерквю, «Церковныя Ведомоти» (dalej: Цер. Вед.), № 14, 13 IV 1900, s. 584-588.

${ }^{30}$ Fabian Gottlieb von der Osten-Sacken - ur. 20 października 1752 r. w Rewlu Estonia, zm. 19 kwietnia 1837 r. w Kijowie na Ukrainie. Podczas wojny napoleońskiej w 1813 r. zdobył Warszawę i Jasną Górę. 
Car Aleksander I ozdobił wizerunek Madonny sukienką ze szlachetnymi kamieniami i przeznaczył go do Soboru Ikony Matki Bożej Kazańskiej w Petersburgu wraz z innymi zdobyczami wojennymi jako wota z wojny z Napoleonem. Świątynia bialska posiadała dogodne warunki rozwoju kultu religijnego, sprzyjało temu połączenie kolejowe z Warszawą, Brześciem i położenie miasta na trakcie pielgrzymkowym do Leśniańskiego Monasteru. Arcybiskup diecezji chełmsko-warszawskiej w 1894 r. zmienił pierwotne plany sprowadzenia obrazu z Petersburga. Wskazał, że konsystorz nie posiada żadnych środków na zakup kopii do Białej. Polecił, by we wszystkich cerkwiach guberni siedleckiej przeprowadzono zbiórkę pieniędzy. Proboszcz soboru miał prowadzić specjalną księgę, do której wpisywał ofiarodawców. W 1895 r. prawosławny duchowny o. Jan Sergijew z Kronsztadu ofiarował 100 rubli na przygotowanie cerkwi do przyjęcia ikony. Na podstawie zachowanych źródeł archiwalnych nie można jasno stwierdzić, czy ikona ostatecznie została przewieziona do bialskiego soboru. W spisach przedmiotów z 1912 r., przeznaczonych do ewakuacji w głąb Rosji bialskiej cerkwi na wypadek wojny, nie figuruje ikona Matki Bożej Częstochowskiej ${ }^{31}$.

Wśród znanych polskich pisarzy, którzy przychodzili na nabożeństwa do soboru, pod koniec lat 80. XIX w. podczas pobytu w Białej na Podlasiu był Stefan Żeromski. Opisy cerkwi i nabożeństw oraz spostrzeżeń na temat wiernych zawarł w swoich Dziennikach ${ }^{32}$. Poza tym sobór często wizytowali prawosławni biskupi zmierzający do Leśnej na doroczne uroczystości. Przybywali do Białej z Warszawy i Chełma koleją, następnie podróżowali konnymi powozami do monasteru. Przybywających zwierzchników Cerkwi miejscowi parafianie witali przed bramą parkanu świątyni chlebem i solą. Ze znanych osobistości, którzy przebywali w soborze, należy wspomnieć bp Tichona (późniejszy patriarcha moskiewski), który 6 czerwca 1898 r., w dniu urodzin carowej Aleksandry Fiodorowej, odprawił w cerkwi uroczyste nabożeństwo. Naczelny prokurator Świątobliwego Synodu Włodzimierz Karłowicz Sabler również odwiedził miasto 26 września 1911 r. i wizytował cerkiew ${ }^{33}$.

Prawosławni duchowni z soboru czynie angażowali się w życie społeczne i kulturalne parafii i miasta. W tym celu prowadzili różne inicjatywy zmierzające do nawiązania nowych kontaktów z mieszkańcami okolic oraz przeciągnięcia opornych unitów na prawosławie. Przy cerkwi działało bractwo cerkiewne zało-

${ }^{31}$ Примечание редакиии, ХВЕВ, № 3, 13 II 1894, s. 50-52; Епархияльныя распоряжения и известия, XBEB, № 4, 27 II 1895, s. 74; APL, ChZD, sygn. 2005, s. 1-4; APL, ChKP, sygn. 4425 , s. 524.

${ }^{32}$ R. Krawczyk, Męczeńskie Podlasie w wybranych utworach literatury polskiej na przełomie XIX i XX wieku, „Szkice Podlaskie” 2001, nr 9, s. 11-12; S. Żeromski, Dzienniki. Wybór, oprac. J. Kądziela, Wrocław 1980.

${ }^{33}$ M. Glinski, Посещение Преосвященным Тихоном Епископом Люблинским Луковского прихода, Леснянсаго женского монастыря и Бельского собора Седлеикой губернии, ХВЕВ, № 22, 27 XI 1898, s. 457-459; Город Бела, ХЦЖ, № 20, 28 IV 1911, s. 609. 
żone przez bazylianów w XVIII w. Posiadało ono księgę z 1835 r., do której wpisywano członków zrzeszenia. Stowarzyszenie otrzymało nowy status w 1881 r., nadal jednak zachowano dawną nazwę Bractwo Narodzenia Przenajświętszej Bogarodzicy. Organizacja ta wyróżniała się spośród innych bractw działających w okolicy intensywnością podejmowanych inicjatyw o charakterze charytatywnym ${ }^{34}$.

Okazją do spotkań w dużej grupie i wymiany doświadczeń duszpasterskich były liczne uroczystości obchodzone w cerkwi raz do roku, np. odpusty: ku czci św. Trójcy, Narodzenia NMP i św. Onufrego. W tym czasie do miasta przybywały pielgrzymki z okolicznych wiosek, prowadzone przez duchownych z takich miejscowości, jak Dokudów, Ortel Książęcy, Kolembrody. Pątnicy przybywali do Białej w wigilie świąt, po czym spędzali całą noc w świątyni na czuwaniu. Następnego dnia po nabożeństwach część pielgrzymów udawała się na uroczystości św. Trójcy do Leśnej, odległej o $15 \mathrm{~km}^{35}$.

Sobór był miejscem ważnych wydarzeń o charakterze religijnym w całej eparchii chełmsko-warszawskiej. Dnia 23 września 1894 r. klucznik Warszawskiego Katedralnego Soboru przywiózł tu cząstkę relikwii prawosławnego św. męczennika Atanazego Brzeskiego z soboru z Brześcia Litewskiego. Następnie po jednodniowych uroczystościach relikwie przewieziono do Leśniańskiego Monasteru ${ }^{36}$.

Prawosławni duchowni z soboru wzięli czynny udział w przedsięwzięciu wzniesienia murowanej kaplicy Matki Bożej Leśniańskiej na miejscowym cmentarzu grzebalnym. Świątynię ufundował w 1901 r. szlachcic z Moskwy - R. Mossakowski, który dzięki wstawiennictwu ihumeni Katarzyny Jefimowskiej z Leśniańskiego Monasteru uzyskał koncesję na założenie apteki w Łodzi. 2 czerwca 1901 r., w uroczystość św. Trójcy (w Cerkwi prawosławnej), nastąpiło przeniesienie kopii Ikony Leśniańskiej do nowej świątyni. Z bialskiego soboru wyszła procesja, której przewodniczył bp Herman z ihumenią Katarzyną i innymi mniszkami. Podczas przemarszu wierni nieśli kopię Ikony Leśniańskiej, wykonanej na pamiątkę pobytu carskiej rodziny na terenie monasteru 12 września 1900 r. ${ }^{37}$

Poświęcenia kaplicy dokonał 3 listopada 1901 r. o. Eulogiusz, wtenczas rektor Seminarium Duchownego w Chełmie. Pokropił on budynek święconą wodą w czasie śpiewu Spasi Gospodi ljudi twoja. Centralne uroczystości rozpoczęły

${ }^{34}$ Братство при Бельской соборной иеекви, ХВЕВ, № 7, 13 IV 1882, s. 116.

${ }_{35}$ Праздник Св. Троицы в городе Белье и пос. Лесне, ХВЕВ, № 13, 13 VII 1882, s. 247-248.

${ }^{36} \mathrm{~A}$. Lewicki, Наступающее торжество перенесення частищы мощей Преподобномученика Афанасия игумена Брестского из Брестского Собора в Леснинский монастырь, ХВЕВ, № 16, 27 IV 1894, s. 262-263.

${ }^{37}$ M. Glinski, Праздник Святой Троицы в Леснинском женском монастыре, XВEВ, № 23, 16 VI 1901, s. 285; APL, ChKP, sygn. 85, s. 294; APL, Starostwo Powiatowe Bialskie, sygn. 196, s. 7. 
się w bialskim soborze, do którego przeniesiono kopię Ikony Leśniańskiej Bogarodzicy. Następnie po skończonym nabożeństwie procesja udała się z ikoną na miejsce nowej świątyni. W pochodzie uczestniczył o. Eulogiusz, który szedł z żezłem ${ }^{38}$ razem z mniszkami Leśniańskiego Monasteru. Matuszka Katarzyna zapowiedziała, że raz w tygodniu do kaplicy będzie przyjeżdżał duchowny z Leśnej razem z monasterskim chórem w celu sprawowania akatystu przed ikoną ${ }^{39}$.

W czasie trwania zamieszek rewolucyjnych w Kraju Nadwiślańskim w 1905 r. bp Eulogiusz przywiózł do świątyni ikonę św. męczennika Pantaleona, którą podarowali prawosławni mnisi z góry Athos. Obecność cennych przedmiotów kultu w świątyni miała powstrzymać od przechodzenia wiernych prawosławnych na katolicyzm, czego spodziewano się po wydaniu ukazu tolerancyjnego przez cara. W krótkim czasie zorganizowano pieszą pielgrzymkę i przeniesiono ikonę do żeńskiego monasteru w Leśnej ${ }^{40}$.

Sobór stał się miejscem manifestacji dla poparcia rosyjskiego imperializmu i samowładztwa caratu. Wielokrotnie organizowano w nim obchody świąt związane z rocznicami państwowymi i kulturalnymi miasta. Najgłośniejszymi uroczystościami, które relacjonowała prasa cerkiewna, były odsłonięcia i poświęcenia pomników.

20 września 1891 r. dokonano poświęcenia pomnika upamiętniającego śmierć trzech rosyjskich żołnierzy w czasie powstania styczniowego. 1 lutego $1863 \mathrm{r}$. w pobliżu Białej oddział powstańczy Rogińskiego zabił trzech wojskowych: Michała Sokołowa, Jewdokima Polanko i Kozaka Maksyma Wołodina z wojska dońskiego. Pierwotnie na mogile poległych ustawiono drewniane krzyże, które z czasem uległy zniszczeniu. Prace związane z postawieniem pomnika trwały cztery lata. W tym czasie zebrano niedostateczne fundusze na budowę w wysokości 75,50 rubli, później dodatkowo uzyskano wsparcie od żołnierzy w Rosji w wysokości 265 rubli. Pomnik zamówiono w odlewni metalów Gejslera w Warszawie. Obiekt posiadał sześcioramienny krzyż z kwadratowym piedestałem, miał 10 stóp wysokości i wykonano na nim napis: „Dzielnym żołnierzom poległym 20 I 1863. Od wiernych rodaków 1891 rok". W czasie odpustu parafialnego w Soborze Narodzenia NMP, po nabożeństwie w świątyni, wyruszyła procesja z chorągwiami i ikonami niesionymi do miejsca mogiły. Uroczystościom przewodził wojskowy chór. Poświęcenia dokonał proboszcz soboru ks. protojerej Michaliewicz ${ }^{41}$.

${ }^{38}$ Odpowiednik pastorału biskupiego w Kościele rzymsko-katolickim.

39 A. Subbotin, Освящение часовни Леснинского женского монастыря в городе Беле Седлецкой губернии, ХВЕВ, № 45, 17 XI 1901, s. 549-550; «Памятная Книжка Седлецкой Губернии за 1911 год», s. 3 (2*).

${ }^{40}$ M. Glinski, Праздник Святой Троицы в Леснинском женском монастыре, ХВЕВ, № 28, 23 VIII 1905, s. 334-336.

${ }^{41} \mathrm{M}$. Semenowski, Сооружение близ города Бель и освящение памятника на могиле трех убитых воинов, ХВЕВ, № 20, 27 X 1891, s. 337-338. 
Wielkim wydarzeniem w życiu społeczności parafii i miasta było odsłonięcie w drugiej połowie października 1900 r. pomnika na cześć pobytu rodziny carskiej w Białej. Pomysł wzniesienia budowli podał naczelnik bialskiego powiatu Bazyli Kiedrow, w sumie zebrano na ten cel 1500 rubli. W tym dniu z soboru przez ulice miasta przeszła procesja. Pomnik o wysokości 11 arszyn w formie obelisku na górze, zwieńczony carskim herbem, został ustawiony na placu miejskim. Na wysokości 2 arszyn widniała inskrypcja: „Na pamięć wizyty miasta przez carską rodzinę 30 VIII 1900" (kal. jul.). Całość ogrodzono metalowym ogrodzeniem. Poświęcenia obiektu w towarzystwie miejskiego duchowieństwa dokonał prawosławny dziekan I dekanatu bialskiego ks. Semenowski ${ }^{42}$.

Podsumowując, Sobór Katedralny Narodzenia NMP był szczególną świątynią w historii prawosławia na Południowym Podlasiu. Cerkiew wielokrotnie odwiedzali liczni wierni, w tym przedstawiciele najwyższych władz państwowych i kościelnych Cerkwi Prawosławnej. Działalność wspólnoty religijnej przerwała I wojna światowa. W II Rzeczypospolitej władze polskie nie wyraziły zgody na reaktywację parafii.

\section{BIBLIOGRAFIA}

\section{Źródla pisane}

Chełmski Zarząd Duchowny, sygn. 24, 76, 2005.

Chełmsko-Warszawski Duchowny Konsystorz Prawosławny, sygn. 81, 768, 781.

Chełmski Konsystorz Prawosławny, sygn. 25, 30, 44.

Klirowyje Wiedomosti, sygn. 6, 50, 54, 55, 56, 62.

Starostwo Powiatowe Bialskie, sygn. 193, 196, 197.

\section{Źródła drukowane}

„ChołmskoWarszawskij Jeparchialnyj Wiestnik”, Warszawa.

„Chołmskaja Cerkownaja Żizn”, Chełm.

„Cerkownyje Wiedomosti”, Sankt-Petersburg.

„Pamiatnaja Kniżka Siedleckoj Guberni”, Siedlce 1875-1813.

„Chołmskaja gubernia 1914 god”, Chełm 1914.

\section{Opracowania}

Bobryk A., Kochan I., Ślady przeszłości. Historia i teraźniejszość prawosławia na poludniowo-zachodnim Podlasiu w świadomości społecznej, Siedlce 2010.

Krawczyk T., Męczeńskie Podlasie w wybranych utworach literatury polskiej na przełomie XIX $i X X$ wieku, „Szkice Podlaskie” 2001, nr 9.

42 Освящение памятника в городе Беле Седлеикой губернии, ХВЕВ, № 41, 26 X 1902 , s. 492. 
Krawczyk T., Zanim wróciła Polska. Martyrologium ludności unickiej na Podlasiu w latach 18661905 w świetle wspomnień, Warszawa 1994.

Osadczy W., Święta Ruś. Rozwój i oddziaływanie idei prawosławia w Galicji, Lublin 2007.

Pelica G.J., Dzieje parafii świętych Cyryla i Metodego w Białej Podlaskiej, „Wiadomości Polskiego Autokefalicznego Kościoła Prawosławnego" 2010, nr 2 (243).

Żeromski S., Dzienniki. Wybór, oprac. J. Kądziela, Wrocław 1980.

\section{SUMMARY}

Orthodox Cathedral of the Nativity of the Blessed Virgin Mary was founded in 1875 with the former church after bazylianach. Since the beginning of the function of parish priests in the parish clergy exercised title protojereja to help were two priests and a deacon. The parish grew rapidly despite the material poverty and the resistance of former Uniates, belonged to the branches: Orthodox church in the city hospital in White, Sławacinek, Wolka Plebańska, Hruda and Cicibor. Orthodox clergy took an active part in the life: cultural, social and parishes of the city and undertook charity among treatment units. Business council was interrupted by the World War I, the estate folk evacuated into Russia, the temple was taken over by Protestants.

Keywords: the orthodox church in the Kingdom Polish; orthodox church; basilian 